\title{
Fantasy In Children Literature
}

\author{
Assist. Lect. Wafa Salim Mahmood \\ Institute of Fine Arts - Ministry of Education- Iraq \\ Email: wafasss@yahoo.com
}

\begin{abstract}
It is necessary to point out that children's literature endeavors to please children and tries to invoke their exciting to stimulate their fantasy. The child in the early childhood can imagine and create or even fly in his imagination, trying to get out above reality and familiarity especially in his games where we find his speak with himself and his toys.

As a genre, there is a connection between fantasy and children's literature. If we remember the immense success of J. K. Rowling's Harry Potter (1977) which represents as a typical model of the role of fantasy in children's literature in the case that it offers the young readers a way to fulfill their place in the world. Thence, fantasy is the best device to make children's literature a means of answering children's enquiries and questions on their attempts of discovering the world.

In this research, The researcher will deal with the role of fantasy in children's literature with its functions and how it affects the child's response by referring to Susan Cooper's The Dark Is Rising, a type of mixed fantasy which combine the heroic and ethical fantasy.
\end{abstract}

Keywords: Fantasy, fantasy literature, children literature, Susan Cooper. 


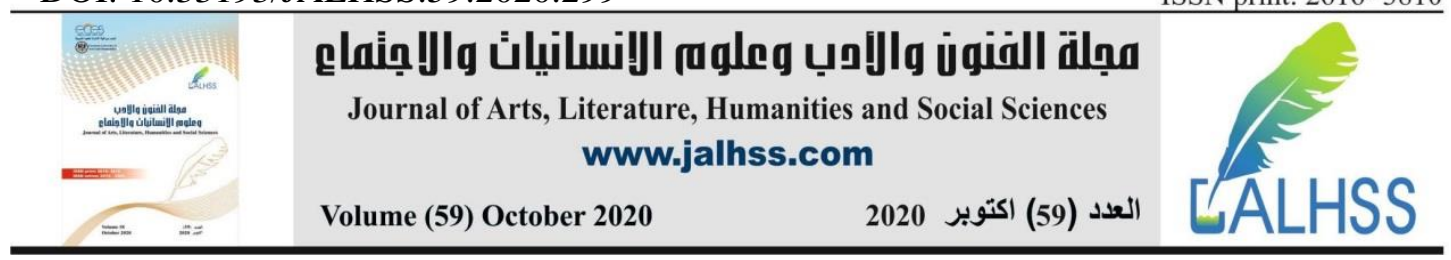

\subsection{Introduction}

In writing about fantasy in children's literature, we first need to focus on its definition and its function in literature in general and then in children's literature in particular. Consequently, the importance of the present research is to shed light on the role of fantasy in any literature as well as in children's literature which the realm of fantasy has a wide space in and takes many forms if the writer wants to employ something like myth, legend or magic in his literary work.

Fantasy is considered the best way to help the writer in urging his readers to response to the literary work in somehow of a sort of imagination intentionally or not. On the sound of that, the aim of this research is to set a theoretical framework of the connection between fantasy and children's literature and here two points would come to our mind and they should be investigated:

1. Children's literature is based on imagination and escapism though nor serious upon the link between fantasy and the child.

2. The link between fantasy and children's literature depends on how the child is depicted as he is growing up in the world of fantasy.

\subsection{The Definition of Fantasy}

Fantasy as a term can be defined into two ways. Linguistically speaking, fantasy is defined as "the power or process of creating especially unrealistic or improbable mental images in response to psychology need" (Marriam- Webster. n.d, 2011). It may also defined as "a pleasant situation that you enjoy thinking about but is unlikely to happen or activity of imagining something" (cambridge Dictionary, 2016). But in literary terms, Fantasy is defined as "a form of literary genre in which a plot cannot occur in real world" (Literary Devices Editors, 2017) .

In both attitudes, the same point comes to the surface which is unreal and in this respect the plot includes magic or witchcraft and the action is occurred in an unusual and unknown places or planets that have not discovered yet. Even the theme could be a combination of technology and something related to legend or myth and may include some animals and unusual creatures talking like human beings.

In his book The A To $Z$ of Fantasy Literature, Brian Stateford ${ }^{1}$ (1948--) defined fantasy as; "the faculty by which simulacra of sensible objects can be reproduced in

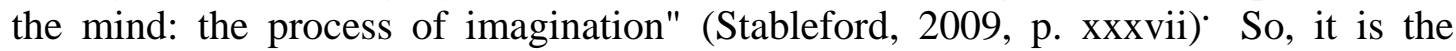
process of how are images firstly depicted in the mind. Others like Gates, Steffel and Molson say that fantasy is defined by the reader himself according to his personal way of thinking and to his experience relying on his life story and dreams or fears as it " raises the images of witches, fairies, dark woods, magic wands, spells, time travel, ghosts and dragon (Gates, Steffel, \& Molson, 2003, p. 1)." In psychology, fantasy refers to "the end of result of mental process of fantasizing (Ibid., p. 2). In this sense, It can be said that fantasy is that process or ability of the mind to depict images of things and how they are settled in the mind of the individual whether they are settled in random way or sequentially, it is the central of daydream (Ibid., p. 7). 


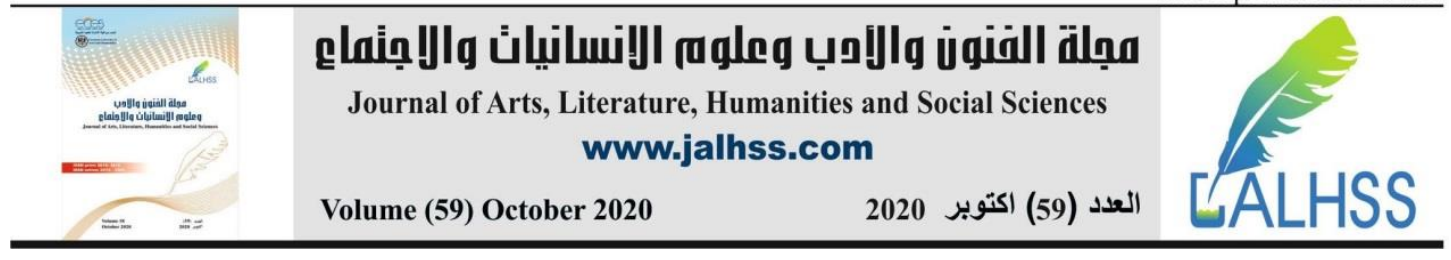

Simply speaking as in the above points of view fantasy is related to the mind. In literature, fantasy then is an imaginative genre that has strange characters and setting ; moreover, in fantasy fiction we can see some points that are different from any other fiction like the events are occurred in places which are not set and performed in usual life. It is all in a sort of imagination. Chaucer also used the word "fantasye" to refer to "a strange and bizarre notions and have no basis in everyday experience" (Stableford, 2009 , p. xxxnii) ${ }^{*}$ This means that fantasy is a conception which is created to be used in literature that takes the reader's mind to unusual experience which is not existed in real life. So it is imaginative. This is called "fantasy Literature" (Ibid., p. xxxvii).

Abrams defines fantasy as an "old fictional utopias"; yet, it takes it its place as an aspired literature depicting the extraordinary among novels such as; Gulliver's Travels(1726) and among the writing of modern times as, J. J. Tolkien's The Hobbit (1937 and The Lord of The Rings (1954) whose plots are incarnated materials from classical, medieval and Biblical stories (Abrams \& Harpham, 2009, p. 323). In addition to Lewis' Alice's Adventure in The Wonderland(1865) and Susan Cooper's The Dark is Rising (1977).All these works and many others incarnate fantasy as an important genre in children's literature.

Apart from this, we can differentiate between "imagination" and "fantasy" in the sense that imagination is so common and it is usually related to real life like daydream. Imagination hints to that capacity of creating things in the mind of the human being. For instance, one can imagine going in a trip to somewhere as he is sitting in his place. So it is a part of everyday life. It can be related to past events or experiences and it may also have a relation to the present i.e. it is based on real experience, whereas, fantasy is related to unreality.

Though fantasy uses imagination in all its cases, it is more than imagination. It often based on unreal and abstract actions so it is correlating to unrealistic world though the two greatest writers J. R. R. Tolkien ${ }^{2}$ and Lewis ${ }^{3}$ have more ideas about the connection between fantasy and imagination.

In Tolkien's view, there are three terms taken in his consideration. First fantasy, for him it is a "freedom from observed fact or primary world. It is both sub-creative art and experience (Sammons, 2010, p. 36). He also adds that fantasy is a "natural human activity" (Ibid., p. 36). Fantasy then for Tolkien is a natural human practice. It certainly does not undermine or contradict logic. That is why he called it "human fantasy" though it is out of human limitation however; it is created by a human who is called by Tolkien "sub-creator". Second, Tolkien moves to define fancy as "images making" as it is similar to human comprehension and it is "a form of memory but is freed from space and time" (Ibid., p. 36). Third, Tolkien defines imagination as; "the analogue to reason and the power of image-making (Ibid., p. 36).

In Coleridge's Biographia Literaria (1817), there was a wide parade for the three terms: "fancy", "primary imagination" and "secondary imagination". Fancy for Coleridge is " a mode of memory". It is a common possession of man while primary imagination is how perceive the world around us and secondary imagination refers to the capacity of making artistic creation. So the two latter terms are the creative state of man (Coleridge, 2004, p. 42). 


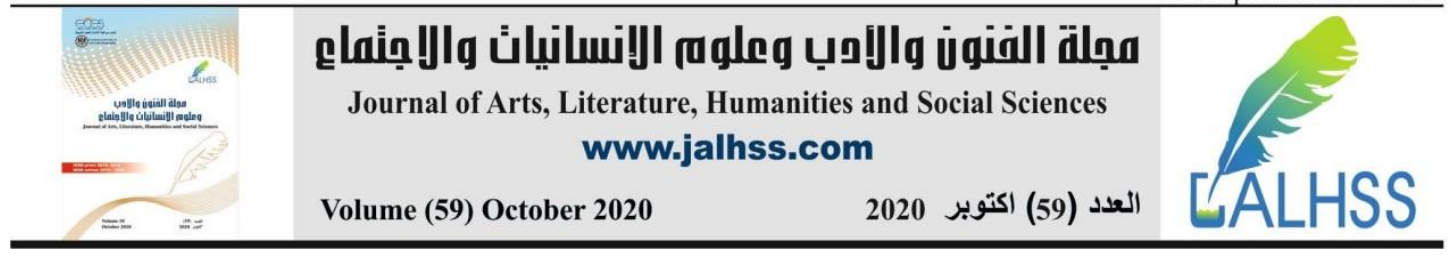

For Tolkien, art is that connection between imagination and the sub-creation i.e., fantasy. This connection is that what he called "the inner consistency of reality" (Sammons, 2010, p. 36). So, it does not obscure the desire for scientific truth and it does not obscure its awareness. On the contrary, the more intense and clear the logic, the better Fantasy produced.

Lewis has another idea about fantasy. He gives us different terms and conceptions. He says that fantasy is different in literature and psychology: literary fantasy is "a narrative that is about impossible and preternatural" While psychological fantasy is "an imaginative construction that may or may not be mistaken for reality. It is morbid castle-building" (Ibid., p,37).

On the other hand, imagination for Lewis is that sort of understanding art. It helps us how to understand the piece of art well and then how to respond to it (Ipid., p,37). For Lewis, imagination is the "source of meaning" and as the reason is an organ of reality, so imagination is the organ of meaning because it makes on reviving the old not causing the truth. Imagination works on the sensation and recognition and thus the mind cannot perceive the objects unless imagination works on it (Ibid., p,38).

Whereas for Tolkien, fancy and imagination are connected by art and the two are manifested by putting fantasies of "fantasy" into imediate action. He adds that the mind is able to create visual representation of the objects that are not exist in reality. Then, the mind tries to arrange the images it creates in a manner and it provides them with "inner consistency of reality". This consistency is achieved by the author to specify a secondary world which either extracted for or flow into reality. That is why the reader in this sense will become a "sub-creator" who fills the world with Elves and goblins (Ibid., p, 41). But Coleeridge define fantasy as a mode of memory emanicipated from the order, time and place, it blended with and modified by that emperical phenomen of will expressed by the choice of words (Coleridge, 2004, p. 144).

In short, fantasy can be definied as that literature by itself which is emanicipated from the limitation of logic. It can be said that fantasy achieves the desired hope and opens the possibility of finding solutions to the most sever concerns depending on the launch of imagination and defeat the limits without being bound by any agreed human laws, often takes place in the world of dreams, magic, mythys and supernatural matters. So, fantasy is a process of expoloration which shares wonderful and strange worlds.

\subsection{Fantasy and Fantastic}

Fantasy and fantastic are two terms which interrelated to each other but importantly and methodologically speaking, there is some difference between the two. As mentioned, fantasy is a condition of the mind to escape from reality into a sort of imagination. thus it is a genre of literature and it mostly called "fantasy literature".

However, fantastic is a term but not a genre because it cannot be separated from the story or the material of the story, nevertheless; sometimes it is tackled to be a genre referring to fantasy. Some critics like Todorov(1939-2017)assured that fantasy is a genre by itself as it raises the interaction between the reader and the action or a 


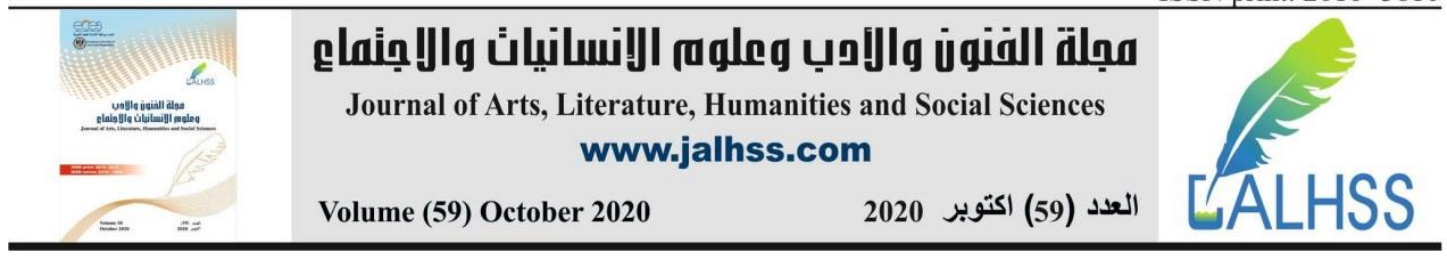

character especially when the reader perceives that the work is belonged to another genre other than literature (Todorov, 1973, p. 25).

As fantasy deals with things like magic, witch, unusual creatures, human animals and so on, fantastic deals with the supernatural aspects which are seen as mysterious and ambiguous. It is a supernatural romance and a part of fantasy. In his book The Fantastic: A Structural Approach to a Literary Theory Genre(1973), Tzvetan Todorov a French critic takes the term "fantastic" in a separate of fantasy and describes it as any event or an action took places in the world and is usually seemed to be supernatural:

"In a world which is indeed our world, the one we know, a world without devils, sylphides, or vampires, there occurs an event which cannot be explained by the laws of this same familiar world" (Todorov, 1973, p. 25).

Todorov's structural approach is devoted to "fantastic" as a specific genre and in his definition, he sets an opposition between what he called the uncanny and marvelous fantasy, the fantastic is governed between the two:

"The fantastic occupies the duration of uncertainty. Once we choose one answer or the other, we leave the fantastic for a neighboring genre, the uncanny or the marvelous. The fantastic is that hesitation experienced by a person who knows only the laws of nature, confronting an apparently supernatural event"(Ibid., p,25).

Concerning the "uncanny", it is that state between the natural and supernatural causes and between the two a possibilities of hesitation is detected to create the fantastic effect (Ibid., p. 25). So in the uncanny, there are peculiar events occurred and then the story is given a rational explanation in the end for instance in the state of madness or dream (Reeder, 1976, p. 187).

On the contrary, the marvelous which he refers to be a traditional visage of fantasy, the reader is familiar with the irrational forces which are presented in the story and cause events that are impossible to be explained like fairy tales or myths and science fiction. The reader here has no reaction towards such forces(Ibid., p,187).

Todorov attempts to set his definition of fantastic according to the reader's response by understanding fantasy through assumptions and doubts raised by the reader himself and thus he defines fantastic accords with the hesitated implication of the reader depending on the structure of the story in the text. He says:

"The fantastic therefore implies an integration of the reader into the world of the characters; that world is defined by the reader's 


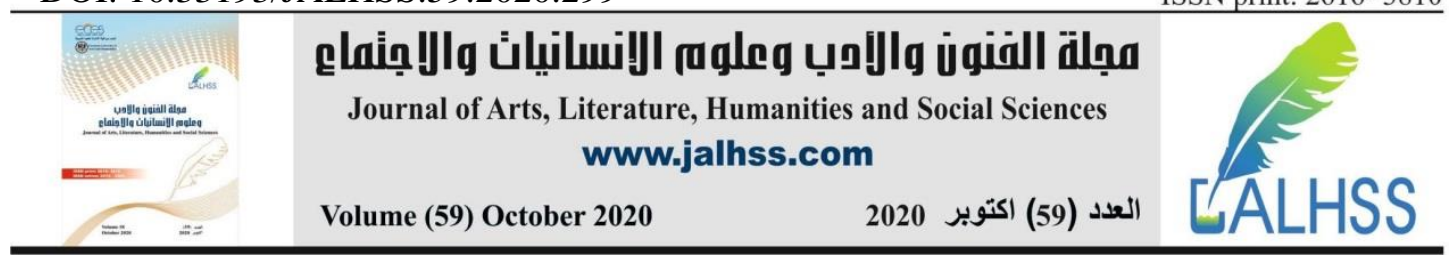

own ambiguous perception of the events narrated".

(Todorov, 1973, p. 31)

Accordingly, fantastic for Todorov is the "hesitation" between the natural and supernatural explanation of some seemingly unnatural phenomenon never be resolved. In this manner, the term "fantastic" has familiar lineaments of "fantasy" due to the fact that the two terms are set up on imaginary things or objects but are not found in reality.

\subsection{Fantasy and Children's Literature}

The child's fantasy is often reflected in his action and behavior thus we find an expression for that in his thump-up where the child imagines himself riding a magic carpet and trying to fly from one place to another. Consequently, the child's fantasy is related to feeling and perception which is based on evoking recognition to reach new images help him for innovation and creation.

Indeed, there are several definitions in the children's literature world which tackles the term 'imagination' but the disparity in degrees of fantasy among children like so, there is imagination and there is fantasy. In children's literature, we find many elements of imagination but we hardly find stories contain fantasy despite that the child aspires in his imagination to place time and fantastic ideas in childhood.

Historically, children's literature or what is called literature of children started to be a type of ideological studies in literature in general and books written for children were set specifically for children in the $15^{\text {th }}$ and $16^{\text {th }}$ century for didactic purposes such as courtesy or behavior books so they served for traditional purposes.

Children's literature in those times was a sub-genre in the realm of literature as whole. It is confined into folk and fairy tales despite the fact that they are regarded the base of the fantasy children's literature.

Gradually stories for children started to appear to be specific and separate genre by itself with the emergence of Newbery's The History of Little Goody Two Shoes (1765) in the $18^{\text {th }}$ century and this novel was considered as the first work written separately for children still they are lacking a little bit fantastic elements as novels of the interested only by upper and middle class families(Hunt, 2005, p.4). It is clear that the works of fantasy children literature spread in the 19th century with the appearance of works like, John Ruskin's The King of Golden River (1851), George MacDonald's The Princess and the Goblin(1872) and Lewis Carroll's Alice's Adventure in Wonderland (1865) (Stableford, 2009, p. xxi).

Those early fantasies followed by other wokss in fantasy children literature such as; J.R.R. Tolkien's The Hobbit(1973) and these fantasies which appeared in this century are not written only for entertaining as those in the previous century but they allow the reader to escape from hid world to present another which is unfamiliar or a world that is unrecognized in real one. In $19^{\text {th }}$ century fantasy children literature includes materials related to education, religion, political and various concepts related to liberation by using fantasy as a means to free the mind of the child social boundaries (Hunt, 2005, pp. 4-5). 


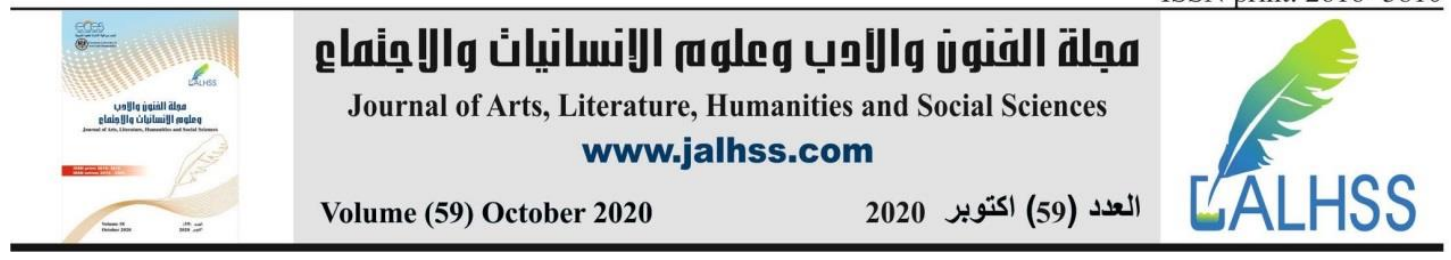

As an illustration, fantasy is not only written for didactic interest or intention but it is also written in a sort of fantasy dream aiming at entertaining the young reader and to please the children with the character for an instance, Alice when she followed a white rabbit entering his hole to find herself in fantasy land with animals able to speak and alive objects.

The reason behind connecting fantasy with children's literature is that what Stableford refers telling that the adult couldn't yield or submit totally to fantasy fiction because this fantasy is just a folly thing and the adult should not give this folly thing thus the term is linked more with children than adults (Stableford, 2009, p. xxxvi).

\subsection{The Function of Fantasy in Children's Literature}

Fantasy cannot be separated from children's literature, on the contrary, it is an important element in the development of literature written for children. Fantasy itself has been developed in children's literature by time from traditional works like myths, legends folk and fairy tales, epics and medieval romance. fantasy uses supernatural elements and magic in both the theme and setting consequently, it is called "creative imagination". It is something like invention and thus its function is to invoke the feeling in the young reader's sensation by using all five senses and by using myths or legends the children are able to imagine the surroundings better than they are in reality based on the fact that imagination is a way of making things visible.

Fantasy is a way of revealing deeper reality in the sense that it makes the young readers capable of experiencing this reality itself and by raising in the mind the imagery of witches, spell, fairies dark woods, ghosts and dragons transform the children into a fantastic world can define the faulty according to their personal way to acquire experience depending on their life stories or dreams and fears (Gates, Steffel, \& Molson, 2003, p. 1).

Fantasy also functions to provide an asethtic experience by making the children amuse with the action by giving insights on the ceation of the characters who are chosen either to be similar or not the young readers:

"Whether seen as aesthetic, social, political, or religious,fantasy, put as objectively and simply as possible, is imaginative fiction that can provide alternative realities, allowing us to explore issues of size, time, and space steeped in the human need to understand good versus evil" (Ibid., p6)

In relating to reality, fantasy is the best way of escapism by bringing things not found in reality and allowed the reader to experience different ways of understanding in seeing the world. It tries to link the world of fiction with the world of reality(Hunt, 2005 , p. 7). This function affirms that fantasy is not only that literature full of supernature but it it is also connected with the features of real atmosphere such as gardens, foods and woods in order to see the good and evil forces well. Hereinafter, fantasy literature must have a child to be the protagonist talking with animals or it could be a talking animal is the protagonists, sometimes talking creatures or a toy 


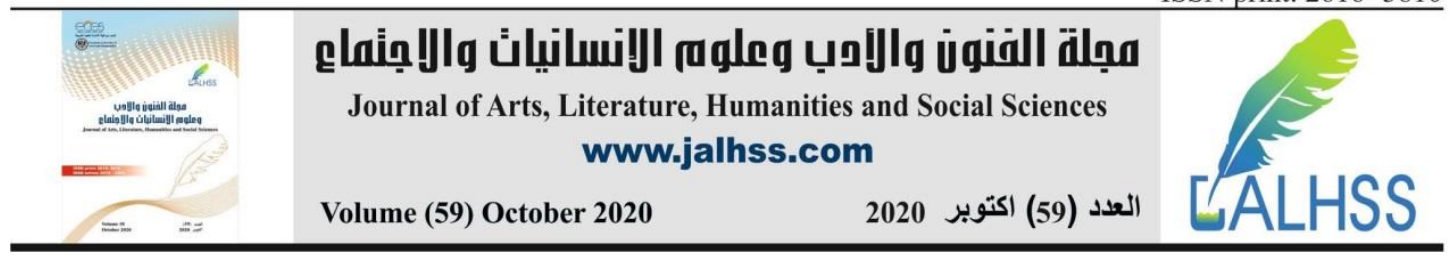

came to be alive (Gates, Steffel, \& Molson, 2003, p. 8), for insrance in making the animal speaks like the rabbit in Alice's Adventure in Wonderland is something unusal and even her journey with the rabbit to the fanciful land is a way to make Alice experience what is beyond the real world.

\subsection{Presenting Fantasy in Children's Literature}

Coming to the point that how fantasy is presented in children's literature. Acually, there are many ways the writer follows in presenting fantasy children literature.Some works like The Hobbit begins and ends with fantasy, others starts in real world but then moves to the fantasy one like Alice in The Wonderland. It can be also find works set in real world but the element of fantasy like magic or spell interlude upon it or it may be by choosing the setting and here, there are two settings will be set in the story, the first one is realistic which is usually called "primary setting" and the second is unreal, it is fantastic and this is called "secondary setting". Another point here to present fantasy is by choosing the characters whom have common nature. They may be not human or they are like human or like the readers and so the reader will easier understand the action but the characters should be associated with heroism using magic and supernatural elements:

" The definitive element of a fantasy story, according to Lin

Carter, is that it assumes and displays the workability of magic. A magical event is one that occurs outside the normal working of cause and effect, by virtue either of the intervention of some supernatural agency or the accomplishment of some kind of formulaic spell".

(Brian, 2005, p. 263)

Fantasy in children's literature has different types, it could be; High fantasy which expresses on that struggle between good and evil, Dark fantasy, Humorous fantasy that aims at entertainment, Low fantasy, Heroic fantasy is related to heroes of myths and legends, Journey fantasy deals with adventures and challenge that solves the mystery and overcoming the danger and strangeness done either by one protagonist or a group of protagonists with or without any help of others like the parents. Historical fantasy which takes its setting from the past events and the characters are depicted as the products of their periods. Even the theme is a universal one but it is not stand in relation to that period. Medieval fantasy, Urban fantasy, Comic fantasy, Juvenile fantasy, Slavic fantasy, Romance fantasy and others. ${ }^{4}$

What is important here is that fantasy in children's literature in recent times has become to be discerned as it belongs to popular tradition and culture to create reality. In this research, two important sub-types of fantasy will be treated as they correlated to the novels under discussion. In the correlation between fantasy and children's literature, there is that type called "Mixed fantasy" as it illustrated by Gates, Steffel and Molson:

"The most common type of children's fantasy is what we call mixed fantasy: children's fiction that combines 


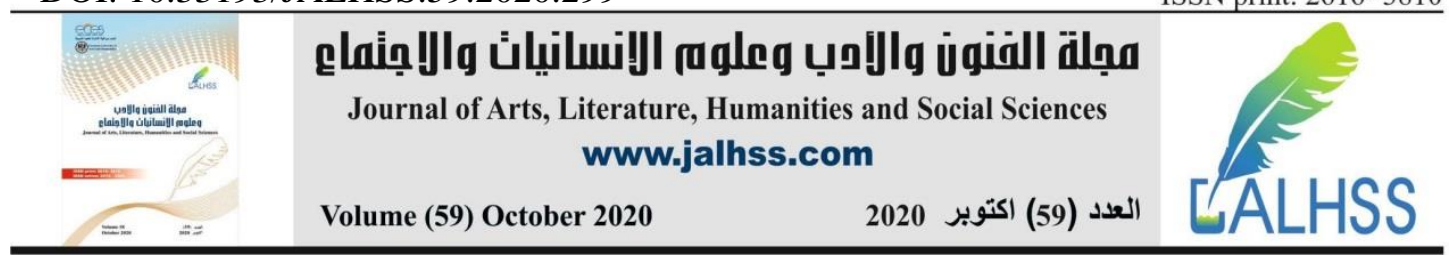

fantasy and realism in various ways and proportions.

The familiar subtypes of mixed fantasy include

journeys (time travel), transformation, talking animals

and toys, and magic" (Gates, Steffel, \& Molson, 2003, p. 49).

In this way, mixed fantasy is that kind of fantasy which adds various dimensions to children's literature by using woods, unusual journeys, peculiar gardens and so on. Alice's Adventure in The Wonderland could be categorized in mixed fantasy because it joins both realism with fantasy.

The other type is called "heroic-ethical fantasy", which is not only heroic, high or ethic but it is also a combinations of them. It is that "adaptation of traditional heroic and mythic conventions"(Ibid., p, 111). This fantasy is based on the protagonist's preference or purposes. The main point in this fantasy is presenting the secondary world that is related to the primary world in three ways; first, the author presents particular fantasy within the secondary world whereas the primary world is discarded. In the second way, the two worlds primary and secondary interrelated to let the reader make a comparison between the two, while in the third, the secondary world will be existed in the primary one by its magical power( ibid., 113). In Cooper's The dark Is Rising, ${ }^{5}$ Will Stanton finds himself reeling between the two worlds but finally returns to The Master Light which is an important document he needs to have secure victory over The Dark.

Characters in this type are mostly noble or belong to high birth performing heroic deeds and the language they speak is mostly formal(ibid., 114). In this subtype, the essence of the dramatized heroism must have the potential to fulfill itself and to convince the young readers' dream or vision.

\section{The Role of fantasy in The Dark Is Rising}

The Dark Is Rising (1973) may have several features of accessible to a wide variety of contemporary fantasy. The story in short tells of a boy in his eleven birthday discovers himself that he is the last of a line of fierce warriors who in conflict with the supernatural powers of The Dark, therefore; he finds himself obliged to enter this battle and complete the mission that his ancestors begin named The Old Ones. The Old Ones as well as Will are able to move and travel by time and place from past to future to find out the secrets he needs to defeat The Dark. The thought of writing the novel comes to cooper's mind during her exile and at that time writing the series of The Dark Is Rising or sometimes called The Seeker is imputed in her mind with the sense of that place more than the place she lived. Consequently, The first element of fantasy in this novel is the landscape. Will Stanton is a perfect example of individual's boundary to home which is considered as a sacred place for him (Carroll, 2011, p. 56). It is the idea of home that governs the mind of the young protagonist. Will's mind sways between the two landescapes. He can neither leave his real home nor his fantasy home for the latter creates him a new identity.

"The image formed itself in Will's mind as naturally as if

he had decided to paint an imaginary landscape and

were making up the look of it before putting it on paper. 


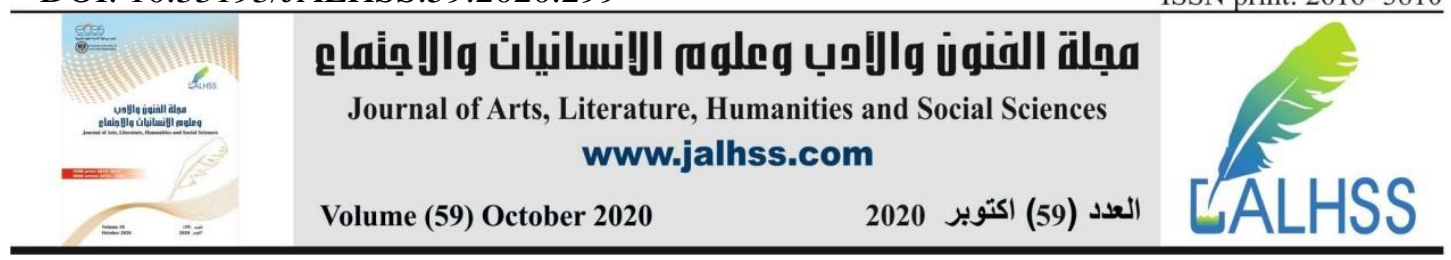

He said, describing the details as they came to him 'There's a grassy hillside, over the sea, like a sort of gentle cliff. Lots of blue sky, and the sea a darker blue underneath. A long way down, right down there where the sea meets the land, there's a strip of sand, lovely glowing golden sand" (Cooper, 2001, p. 30).

Throughout the novel, there is an actual and emotional change that occurred in Will's personality. He comes to an awareness that his home could no longer be a protect place. That is why he tries to make a negotiation to balance the two places, his family and the new life as an Old One but also to restore the balance between the two worlds rededicate the boundaries of his own world and prevent the Dark from invading again (Carroll, 2011, p. 66). Home for Cooper is very important. It is symbolic and very complicated. It is too firm for a one to live in a refugee or in a prison. So, Cooper wants the children to fascinate home and to imagine its value and to be tied with their home from early childhood. She wants the reader to recognize the place he lives in and to cling with a place, physical place.

Another element of fantasy in The Dark Is Rising is the everlasting struggle between the Light and the Dark i.e., Good And Evil. These two poles are of course the opposing powers of the world and the sequences of their conflict have been become extreme subjugation or liberation of the human race to establish its own fate. The physical objects of The Dark Is Rising are taken part in the character's sensation of the hidden powers or events.

Coming to title of the story refers to an element of fantasy in it. Dark is a word related to night in reality but here it something like a human and to rise so it is a metaphor which is a fantasy, for Cooper it is one of the two forces that govern the universe. So, the theme is that conflict between $\operatorname{good}(\mathrm{Light})$ and evil (Dark). The story is based on Arthurian legend and Celtic. Cooper depicted the Welsh and Cornish folklore as well as Medievalism. With the succession of the quests to fight the last battle between the good and evil. Even the protagonist is chosen to be related to legend and this is another element of fantasy, Will Stanton, the last member an immortal group of being known as the Old Ones who in a fully struggle between The Dark and the Light (Goodrich, 1988, p. 166). The archetype conflict in the novel is played in between two parall realities in a historical framework( ibid., p, 166). The child, Will is trasformed between his real pimary world i.e, his family and the fantasy secondary world with Merriman and the myserious woman who told him that he is the last of the Old Ones, the gurdian of the Light:

"Merriman smiled. 'In a way. In a way.'

Then he was sombre again. 'Listen now.

The gift I speak of, it is a power, that

I will show you. It is the power of the

Old Ones, who are a sold as this land and

older even than that. You were born to inherit it, 


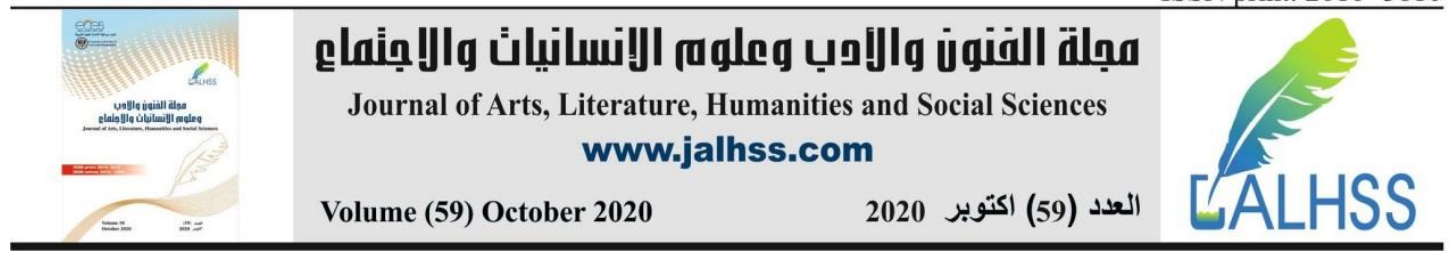

Will, when you came to the end of your tenth year". (Cooper, 2001, p. 29)

Will has become archetype invites the reader to be in a deep union with himself and to be close with the world. defintely, the function of fantasy is to develop the awareness of the protagonist and the reader of their weakness and strength so that they can face the problems. Kowing his strength, Will with the help of Merriman will obtain the capacity of practicing magic and supernatural power to defeat the enemy but if he should first gain the Thing of power,or "gift of power":

"Make no mistake about that. Any great gift of power or talent is a burden, and this more than any, and you will often long to be free of it. But there is nothing to be done. If you were born with the gift, then you must serve it, and nothing in this world or out of it may stand

in the way of that service, because that is why you were born and that is the Law." (Cooper, 2001, p. 32)

In Cooper's books, there is that the chracters' responding to a gift whose 'burden' cannot be escaped because in their fantasy they are too bound to it (Krips, 1992, p. 169). the Six Signs which are the representative of Light in order to fulfll the mission and use them togteher in defeating the Dark:

" When the Dark comes rising, six shall turn it back;

Three from the circle, three from the track;

Wood, bronze, iron; water, fire, stone;

Five will return, and one go alone". (Cooper, 2001, p. 33)

One of the elements of fantasy is that the hero seeks for percious Objests by making a journey facing Gurdians that he should overcome to obtain the goal and win. So, the function of the signs here is to play with protagonist's role to have free will and to aqcuire the capacity of change and by collecting them together means to unify the character's strength to defeat the Dark. Each time Will face a Guardian (The Walker) through his quest for the Sign (Plane, 1986, p. 38).

Fantasy in The Dark Is Rising endeovors to make the character share his/her sense of the hidden powers he/ she owns at work and event. Moreover, the dreams, fears and wishes all become a sluiceway between these hidden forces and historical events (Goodrich, 1988, p. 169). Fantasy in this novel is used as a means to escape or transcend from the ordinary physical and mental limitation. Accordingly, in fantasy there is that relation between conscious and unconscious in the part of the protagonists. The consious usually controls the mind. Will and Merriman, by the transcendent forces threaten the mental balance of human, restore theie security by erasing their memories. Copper strongly detached Dark and Light from the imparial world and reduced the characters' conscious memorirs to dream which are very important because they expose the human nature(Ibid., p, 170). 


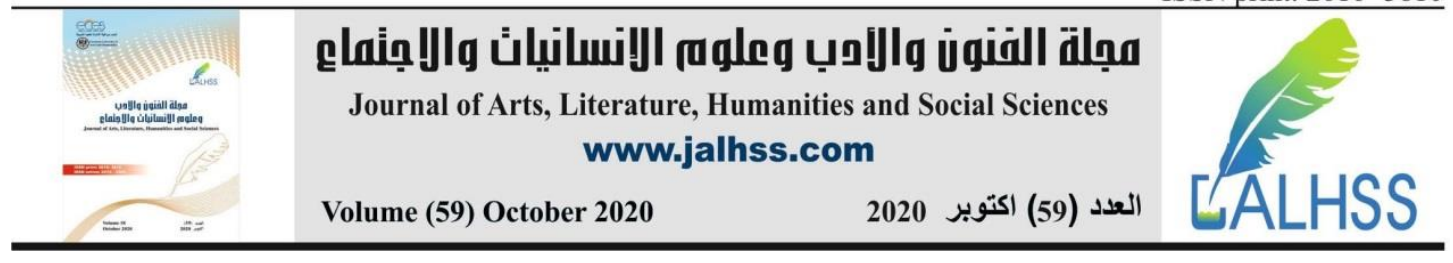

The myth that Susan Cooper uses has two functions; the first is to entertain the children as readers and the second is to give a message about heroism. Will's quest or search for the Signs and for anything else indicates the development of his selfknowledge and his personality. The landscape that he journnies in his unconscios mind develops his insight on the real world he lives in to differntiate beteen good and evil, therefore; the fantasy in this novel attemps to develop the reader's understanding of many experiences wether pholosophical, social, ehical and even psychological. Magic and spell is used in The Dark Is Rising is abnother indication of fantasy in children's literature with purpose of entertaining and raising the child's perception. Will and Merriman rush to the sea to work the spell that will assit them to restore the needed manuscript.

\section{Conclusion}

Children's literature is that genre written for young readers and it concerns with ideas and language are almost be very simple and concepts taught for children that giving moral lessons. Children's literature may pointed out by using stories either taken by tradition or classic fiction or folklore that are yield to young readers especially by inserting fantasy in the events which appeals to any story that tackles with the impossible and supernatural. The goal of using fantasy in children's literature is to invoke the children's imagination and critical thought to encourage them develop their mental understanding of the world. Fantasy serves the narrative in creating tension and develops the plot and organizes it in depicting strange world that has no real existence outside of language.

\section{Footnotes}

1. Brian M Stableford (1984- ) is an author of about 75 books including 50 novels. He was an academic in UK from 1977- 1988 before turning to witting full-time. He is also a critic, translator with a degree in Biology and Ph.D in sociology. his writings deals with science fantasy and psychology of social adaptation.

See: http://www.sf-encyclopedia.com/entry/stableford_brian_m

2. John Ronald Reuel Tolkien (1892- 1973), a scholar of English language who is specialized in old English language though of a German origin when his grandfather came to Britain in 1772 and quickly became an Anglicized. Thus Tolkien is regarded an English writer, philologist, poet as well as an academic at the University of Oxford. Tolkien wrote a number of fantasy works such as The Hobbit (1973) and The Lord of the Rings (1945-1955).

\section{http:// www. tolkiensociety. org. / author/ biography/}

3. Charles Lutwidge Dodgson, known as Lewis Carroll(1832-1898) was born in England and became a teacher of mathematics at Oxford and a deacon of the Anglican Church. He wrote many poems in addition to prose mostly in children's literature and he was known for his writing, Alice in The Wonder world in 1865. 4. See Stableford, B.M. (2005). Historical Dictionary of Fantasy Literature. Lanham: The Scarecrows Press. 


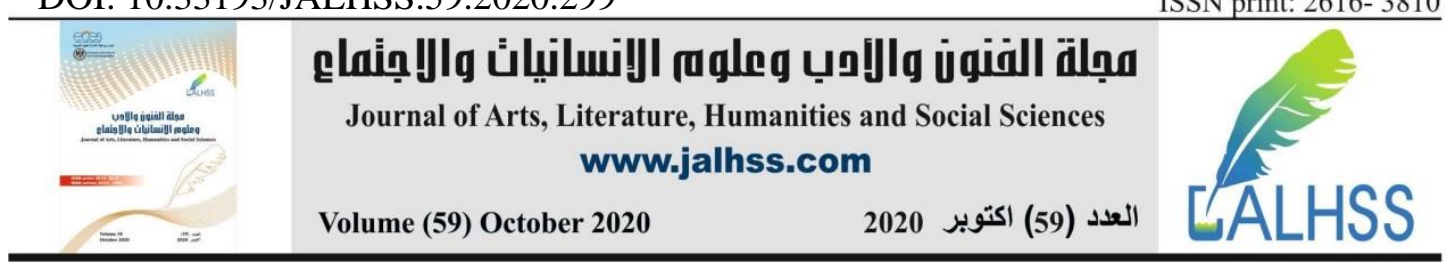

5. Susan Mary Cooper (1935-) is an English author of children's books, best known for The Dark is Rising Sequence. a contemporary fantasy series in England and Welsh. She frequently incorporates British mythology into her works such as Arthurian legends, and Welsh folk heroes. A prolific author, she has written twentytwo children's books, four screenplays, a dramatic play, two biographies, and two works of nonfiction. In 2012, she won the lifetime Margaret A. Edwards Award from the American Library Association, recognizing for the contribution to writing for teens

[Wikipedia contributors. (2020, March 26). Susan Cooper. In Wikipedia, The Free Encyclopedia.

from https://en.wikipedia.org/w/index.php?title=Susan_Cooper\&oldid=947520892]

\section{References}

1. Abrams, M. H., \& Harpham, G. G. (2009). A Golossary of Literary Terms (Vol. 9th edition). Boston/ Wadaworth Cengage Learning: Michael Rosenberge.

2. Brian, M. S. (2005). Historical Dictionary of Fantasy Literature. lanham: The Scarecrow Press..

3. Carroll, J. S. (2011). Landescape in Children's Literature. Routledge: Tylor \& Francis Group.'

4. Coleridge, S. T. (2004). Biographia Lteraria. Princeton: Princeton Unvercity Press.

5. Cooper, S. (2001). The Dark Is Rising.Throndike Press.

6. Dictionary, W. (n.d.). WWW.Marriam. Webester. com/dictionary/fantasy.

7. Fantasy. (2016). In Cambridge Dictionaries.org. Retrieved from http://www.Cambridge . org/dictionary/english/fantasy

8. Gates, P. S., Steffel, s. B., \& Molson, F. J. (2003). Fantasy Literaure for Children and Young Adults. Lanham: The Scarecrow Press Inc.

9. Goodrich, p. (1988, December). Magical Medievalism and The Fairy Tales in Susan Cooper's The Dark is Rising. The Lion and the Unicon, 12, pp. 165-177.

10. Hunt, P. (2005). Understanding children's literature: Key essays from the International Companion Encyclopedia of Children's Literature. London: Routlege.

11. Krips, V. (1992). Finding One's Place in The Fantastic: Susan Cooper's The Dark Is Rising. In J. Sanders (Ed.), Functions One's Place in the Fantastic: Selected Essays from Thirteenth Internation Conference on the Fantastic in the Arts.

12. Literary Devices. (2017, May 1). Retrieved December 5, 2017, from https://www.literarydevices.com/

13. Plane, R. L. (1986, Spring). Objects and Chracter in The Dark Is Rising. Children's Literature Association Quarterly, 1, pp. 37-41 


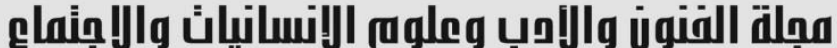 \\ Journal of Arts, Literature, Humanities and Social Sciences www.jalhss.com}

14. Reeder, R. (1976). Tzvetan todorov. The Fantastic : A Structural Approach to a Literary Genre (2 ed., Vol. 20). Yale: Slavic and East Europeon Journal.

15. Sammons, M. C. (2010). War of fantasy Worlds: C. S. Lewis and J. R. R. Tolkien on Art of Imagination. United States: Santa Barbara.

16. Stableford, B. M. (2009). The A To Z of Fantasy Literature. Lauham: Searecrow Press Inc.

17. Todorov, T. (1973). The Fantastic: A Structural Approach To A Lierary Genre. (R. Howard, Trans.) Cleveland/ London: The Press of Case Western Reserve University. 